Article

\title{
Applying System-Oriented Sustainability Scoring for Cruise Traffic Port Operators: A Case Study of Geiranger, Norway
}

 \\ 1 Department of Ocean Operations and Civil Engineering, Norwegian University of Science and Technology, \\ 6009 Ålesund, Norway; vilmar.aesoy@ntnu.no \\ 2 Department of International Business, Norwegian University of Science and Technology, \\ 6009 Ålesund, Norway; dina.aspen@ntnu.no \\ 3 Department of Industrial Economics and Technology Management, Norwegian University of Science and \\ Technology, 7491 Trondheim, Norway; magnus.sparrevik@ntnu.no \\ * Correspondence: borge.a.h.johansen@ntnu.no; Tel.: +47-91564208
}

check for updates

Citation: Johansen, B.H.; Aspen, D.M.; Sparrevik, M.; Æsøy, V.

Applying System-Oriented

Sustainability Scoring for Cruise

Traffic Port Operators: A Case Study of Geiranger, Norway. Sustainability 2021, 13, 6046. https://doi.org/ $10.3390 /$ su13116046

Academic Editor:

Manuel Rodríguez-Díaz

Received: 31 March 2021

Accepted: 4 May 2021

Published: 27 May 2021

Publisher's Note: MDPI stays neutral with regard to jurisdictional claims in published maps and institutional affiliations.

Copyright: (c) 2021 by the authors. Licensee MDPI, Basel, Switzerland. This article is an open access article distributed under the terms and conditions of the Creative Commons Attribution (CC BY) license (https:// creativecommons.org/licenses/by/ $4.0 /)$.

\begin{abstract}
Balancing the positive and negative impacts of cruise tourism is a challenging task for port operators. Necessary information for cruise port planning and decision making may be laborious to acquire and further combine for holistic decision support. The current study applies a systemoriented sustainability scoring model to the port of Geiranger, Norway. The aim is to provide a practical and low-threshold approach for appraising sustainability aspects in cruise port planning and decision making. The scoring model provides an estimate of performance on sustainability indicators based on cruise call itinerary information and readily available ship data. Results demonstrate how using the scoring model can prove useful for both port management, planning, stakeholder communication and scenario evaluation.
\end{abstract}

Keywords: cruise ship; sustainability; indicators; tourism; systems thinking; port management

\section{Introduction}

Global cruise tourism passenger numbers increased by nearly 70\% from 2009 to 2019 [1]. Although the coronavirus disease 2019 (COVID-19) pandemic had a significant impact on the industry in 2020, growth is expected to pick up again in the next few years [2]. Port cities and vicinities near popular cruise destinations benefit from jobs and revenue enabled by the industry. Conversely, there are strains that need to be dealt with The environmental and social impacts of cruise ships are often concentrated in areas of high natural and cultural value [3]. Klein [4] points out "people pollution" (crowding), homogenization of the port experience, and the reduced authenticity of cultural experience as potential negative social impacts from cruise activities. The economic gains are also challenged as the expansive offering of onboard cruise ship activities may negatively influence the cruise passengers' local spending at cruise destinations. This may lead to an uneven distribution of costs and benefits between the cruise lines and the community ashore at destinations [5-8]. Balancing these positive and negative impacts of cruise tourism is a challenging task for local decision makers and the information available to support decisions for managing visits from cruise ships is often limited.

Through system development, the cruise ship-at-port system is explored according to the feasibility to support decisions on which cruise ships to admit as well as invoking measures countering strains to the port and its vicinity. Building upon the prior works of utilizing systems to understand tourism systems, the current study aims to develop and apply a sustainability scoring model for cruise ships. The purpose of the proposed model aims to provide port operators with a practical approach for evaluating how cruise calls perform on indicators representing environmental, social and economic dimensions of sustainability analogue to the triple bottom line framework [9]. The proposed model will further be applied to a case study on the port of Geiranger, Norway. 
Section 2 of this paper describes the theoretical framework for the study drawing experience on previous studies. Section 3 describes the methodology in the proposed systems-based scoring model approach and Section 4 demonstrates how the scoring model could be applied in planning and management, stakeholder communication and scenario evaluation. Section 5 concludes the work and provides ideas on further development and application of the scoring model.

\section{Background}

Cruise tourism in the context of sustainability in research is a relatively recent and small field of science, with few publications before Ritter and Schafer [10] called for more academic scrutiny of the industry. Since then, several scholars have focused on the environmental impacts of cruise tourism $[3,11]$. This includes in particular emissions to air in port cities [7,12-19] and addressing them in terms of economic externalities [20-22]. Johnson [23] points not only to the cruise operators and destinations but also calls for the tourist to use their market influence to invoke changes towards more sustainable cruise tourism. Brida and Zapata-Aguirre [24], look at the economic, environmental and sociocultural impacts of cruise tourism asking if there is certainty that the benefits of cruise outweigh the costs. Although they do not fully answer the question, they invite decision makers in cruise tourism destinations to not blindly implementing efforts to increase cruise tourism without thorough consideration of potential gains and challenges. Klein [4] looks at cruise tourism through the "responsible tourism lens", focusing on "(a) tourism's impact on the environment, (b) the equitable distribution of economic benefits to all segments of a tourist destination, and (c) minimizing negative sociocultural impacts" and the purpose of this framework is to consider the sustainability of cruise tourism in the perspective of the port community. The studies mentioned above are important conceptual papers, but they lack practical means of providing and structuring sustainability information to port operators.

Hritz and Cecil [25] looked at a case study on Key West, Florida, to construct sustainability indicators for cruise tourism focusing on current and potential resources, demographics of local residents and cruise passengers, economic structure and tourism demand-supply relationships. The study uncovered opinions on the indicators from different stakeholder groups and made up a structure to monitor future policy changes to cope with rising tourism. A similar approach, focusing on local stakeholders, was undertaken by Pomeranz, Needham and Kruger [26] regarding a coastal protected area in Alaska, US. Other studies on stakeholder perspectives of cruise tourism have been conducted since focusing on the perspectives of local residents [27,28]. Stefanidaki and Lekakou [29] introduce their conceptual approach "cruise-carrying capacity" based on the drivers, pressures, social processes/state, impacts and responses (DPSIR) relevant for cruise tourism. Based on an extensive review Stefanidaki and Lekakou [29] also provide a comprehensive set of sustainability indicators for cruise destinations in their framework based on a literature review and dialogue with experts. The indicators were derived from literature review and discussion with peers within cruise tourism research. The set of indicators are comprehensive and broad in scope and would provide to a high degree an exhausting set of parameters for societal planning and policy making on a national or regional governmental level. Wu, Chen and Min [30] built upon the work of previous studies building a set of indicators for cruise tourism sustainability for assessing regional sustainability conditions and cruise-industry development. Albeit being comprehensive and focusing on broad aspects of sustainability related to cruise tourism from the perspective of ports, the latter two indicator schemes would be too comprehensive for most port authorities to implement. In order to acquire useful information for sustainability decision support it is useful to comprehend the tourism industry as a complex and dynamic system of close and interdependent ties between components [31] p. 34. A port city-with its inhabitants, businesses, infrastructure and nature-being visited by a cruise ship and its passengers could be considered as such a system. Arnold and Wade [32] define systems thinking 
as " ... a set of synergistic analytic skills used to improve the capability of identifying and understanding systems, predicting their behaviors, and devising modifications to them in order to produce desired effects ..." ". This includes understanding the system structure and its dynamic behavior. Systems thinking approaches have been applied in tourism focusing on e.g., organizational learning [33], future simulation [34] and mapping the effects on climate change from marine tourism [35]. Other recent examples of a systems thinking approach for establishing sustainability indicators are e.g., Stanitsas et al. [36] -in the construction industry and Steiniger et al. [37]—for urban sustainability indicators. More specific to the topic of the current study are Coccossis and Koutsopolou [38] for monitoring sustainability of coastal tourism; Schianetz and Kavanagh [39] for making sustainability indicators for tourism destinations; and a more broad-reaching scheme by Roxas et al. [40] using causal loop diagrams.

\section{Materials and Methods}

The current study evaluates a model for establishing sustainability indicators for decision support in cruise ports based on a systems thinking approach-seen from the perspective of the port. In this context, multiple systems are interacting. Firstly, there is the cruise ship with the purpose of transport, accommodation and entertainment of tourists which in itself embodies the characteristics of a system. In the context of sustainability, cruise ships interact with natural surroundings and socio-technical structures of the port cities, which also make up a new system that results in desired effects and the opposite. Examples of these sub-systems are the cruise ship-emission/discharge to nature system; cruise ship-road traffic system; and cruise ship-tourist distribution system; opposed to the cruise ship-local business system. These systems encompass both spatial and temporal boundaries together with interactions on other systems and stakeholders that also should be addressed in a cruise call sustainability scoring approach.

The literature assessed in Section 2 does not provide a practical and low threshold approach for appraising sustainability considerations in cruise port planning and decision making. The authors of the current study therefore propose a model for establishing sustainability indicators for decision support in cruise ports as shown in Figure 1. The model builds on a five-step procedure to analyze and evaluate sustainability impacts of cruise calls to port based on cruise ship characteristics and to use the output for decision support. The main focus of this paper is, hence, to demonstrate and evaluate the suitability of the model by using it on a test case of the port of Geiranger, Norway.

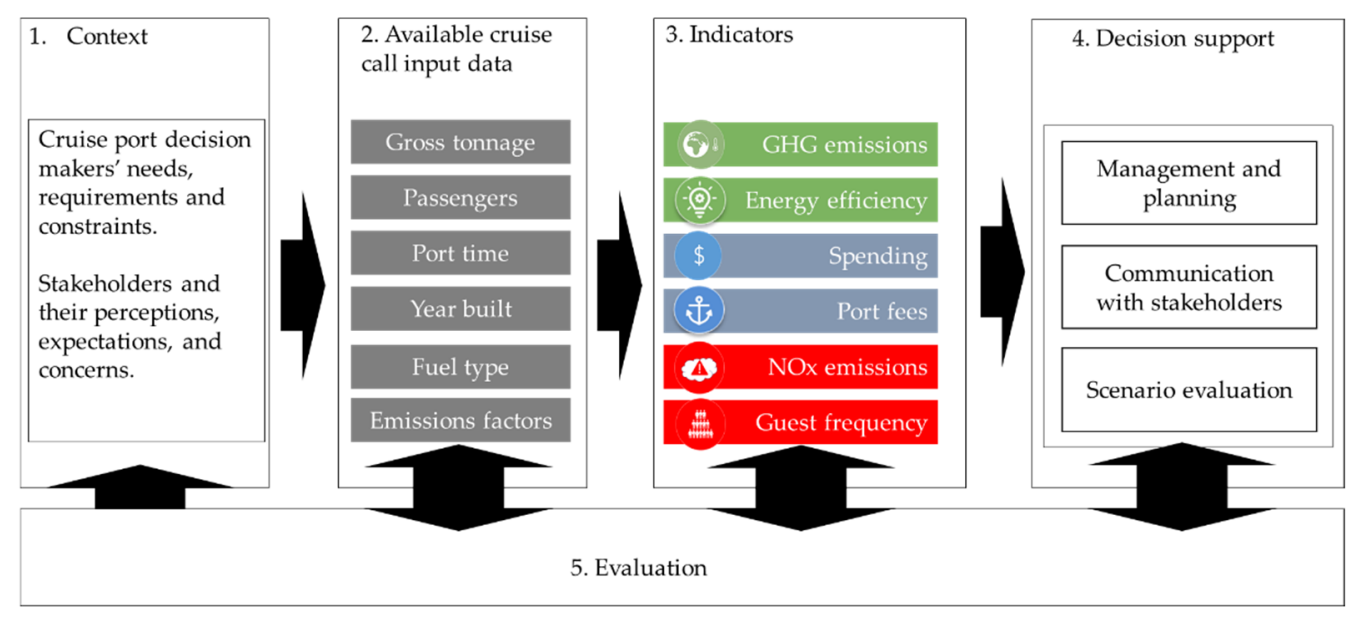

Figure 1. Proposed cruise call sustainability scoring and decision support model. 
Firstly, the context of the cruise destination system is defined, including cruise port decision makers' needs, requirements and constraints together with stakeholders and their perceptions, expectations and concerns. The concerns and wants of the stakeholders should be addressed in the indicators used to explain phenomena in the system. Cruise tourism destinations have great variation based on both demography and society. This provides different profiles of stakeholders. Popular cruise tourism destinations span from large cities like Barcelona and Miami to rural societies like the Norwegian fjords or small Caribbean island societies. The relative impact and focus of cruise tourism to stakeholders vary according to this as it in big cities is one of many systems affecting sustainability while it at smaller societies may be a dominant activity regarding economic development and hence the accompanying externalities. The distribution between gains and externalities is also an important aspect. Although stakeholders want to influence, the reality is often that economic and societal structures make up boundaries for involvement and many are aware and accept this but expect at least to be informed and to be heard [41]. Choosing the correct indicators for communication of impacts is an important part of this as they should represent the information requirement.

In the second step, the port operator selects data to compute indicators. The minimum required data are the number of passengers (PAX), gross tonnage (GT), year built and duration of the stay. This is information that significantly correlates to environmental impacts [16]. The second step also consists of informing the model with other available ship data and the planned itineraries or port calls. The approach proposed in this paper is also open for further information to be added, as it will inform the model better and provide more precise impact estimates.

In step three, the indicators for the cruise call sustainability scoring system should reflect the needs uncovered in the first step, while still being quantifiable through the available data mapped in step 2. According to Waas et al. [42] an indicator represents an attribute of a system that is given by a variable and its value. The attribute may be a quality, characteristic or property while the variable may be expressed using a quantitative or qualitative value. System stakeholders should be involved in the development of indicators. Additional literature and resources could also be utilized in the indicator synthesis process. The output of the exercise is a description of the indicator system properties and ultimately its synthesis. The indicators in the sustainability scoring model presented in this paper were established together with professionals at the Port Authority through a series of workshops. The literature discussed in Section 2 of this paper was used to establish a predefined set of indicators, which were presented and discussed among workshop participants. The indicators were evaluated with regards to how they provide valuable information for sustainability decision support, if the required data for calculating values are at hand and whether they are possible to implement. The approach is iterative, meaning that the practitioner should do adjustments on the indicator based on feedback from the Port Authority between workshops.

The fourth step includes taking the information provided by the indicators at the given context into account when making decisions. It is important to firstly understand the dynamics behind the elements of the systems being managed or considered for some act of change-making. How will management or change influence the different stakeholders of the systems? Will the decision have the desired effects on the impacts of sustainability? Will the decision provide a balanced solution within all three dimensions of sustainability? The scope of decision making could vary between day-to-day operations like management and planning to more long-term uses like scenario evaluation, e.g., Pesce et al. [43] utilized indices of different sustainability aspects in the decision making about different routing options for cruise ships at the port of Venice, Italy. The indicators could also be used for communicating to stakeholders "the state of sustainability" at the cruise tourism destination.

Lastly, each step includes evaluating the indicators with the requirements and desired attributes stated by the decision makers. In this step one also reviews what has been done 
in the other steps and check if improvements could be achieved before implementation of the indicator set. This step is inspired by other circular Systems Engineering approaches like the ones by Fet [44] and Haskins [45]. Analysts using this approach need to evaluate whether the data, models and indicators being used to estimate impacts to sustainability are in line with the desires and concerns of stakeholders. It must also be considered whether the output is understood by stakeholders and gives them valuable input. Either it is decision makers who need the background to make informed choices or stakeholders who require and/or deserve to be kept in the loop.

\section{Results and Discussion}

\subsection{Step 1-Context}

The sustainability scoring model is applied within the context of the port of Geiranger, Norway (Figure 2). The first step was taken through document analysis, participating in relevant meetings with stakeholders for the port and working meetings with Stranda Port Authority. The primary systems identified were the cruise ships calling to port and the port destinations with which they interact. A key functional requirement of these indicators is to determine how cruise calls positively and negatively influence the port destination. Critical constraints encompass the time and other resources needed for accessing and modeling data to compute sustainability indicators.

In order to provide meaningful information for decision support for the three purposes given in Figure 1, step four-an overview of the given ports present and future challenges is needed. The quay is situated in a small village with 240 permanent residents, surrounded by steep mountains ranging over $1400 \mathrm{~m}$ above fjord level. Geiranger admitted 402,335 cruise passengers in 2019, ranking 3rd in the country [46]. The rising influx of tourists to Geiranger up towards 2019 has led to a debate on the negative effects of mass-tourism and particularly cruise tourism and its accompanying emissions is under much public scrutiny $[17,47,48]$ and perceptions about tourism from local stakeholders are mixed [49], while tourists are generally quite satisfied [50]. The scrutiny has led to actions taken by both local and national government from capping the total daily number of cruise passengers to Geiranger at 6000 by the local port authority to the National Parliament passing a bill requesting that only zero-emission ships shall operate in the World Heritage Fjords by 2026 [51]. Before this, amendments on the shipping emissions for the same area were laid down by the Norwegian Maritime Authority (NMA) to only admit ships with IMO tier III emission standards for NOx by 2025 [52].

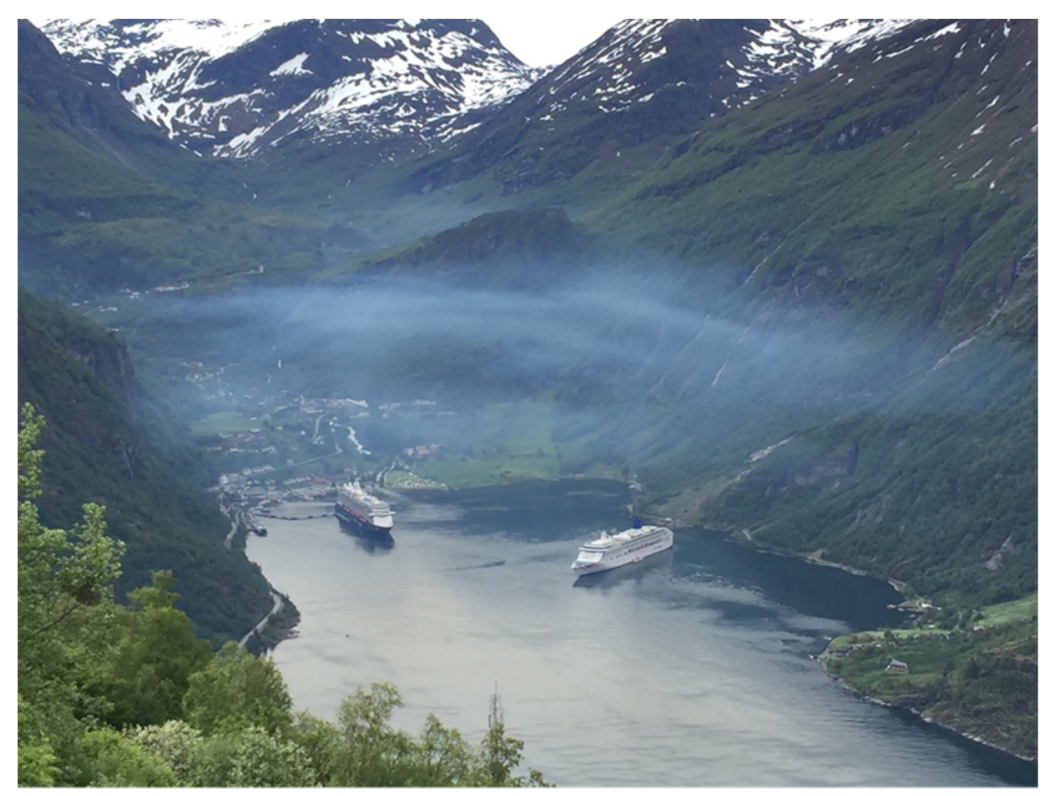

Figure 2. Port of Geiranger, Norway. Photo: First author. 


\subsection{Step 2-Available Cruise Call Input Data}

For the second step, data from the port of Geiranger, Norway, from the years 2015 to 2019 were made available from Stranda Municipality Port Authority. This includes the time of arrival and departure of the cruise ships. Based on the cruise ship name as an identifierdata on key ship characteristics were extracted from the IHS-seaweb [53]. Two indicators from each of the three dimensions of sustainability are proposed for the sustainability scoring model (Table 1). The indicators follow the taxonomy given by the triple bottom line framework [9] and Kleins [4] responsible cruise tourism lens, being respectively well known and frequently cited works in the literature on general sustainability and cruise tourism sustainability. Establishing indicators within these dimensions gives a clear structure both on how to utilize indicators for decision support and communication. The indicators are calculated from input variables normally found in cruise call itinerary information kept by port authorities. The input variables were also confirmed by Norwegian cruise port authority representatives. Gross tonnage is the weight of the ship. Port time $\left(t_{p}\right)$ is how long the cruise ship is docked at port either on a quay or at anchor as passengers are landed. PAX is the number of passengers onboard the ship. Year built (YB) is the year the cruise ship was built. The idea is to keep the indicators in the proposed scoring model easy to implement and use for local port authorities as they seldom have the resources to undertake sustainability assessments of the cruise calls they receive. With the scoring model, they can do rough sustainability assessments of each cruise call and be able to use the information when planning itineraries for future cruising seasons as port callings often are booked a couple of years in advance.

Table 1. Input variables needed to determine the scoring model indicators.

\begin{tabular}{|c|c|c|c|c|}
\hline Input Variable & Unit & Indicator & Reference Aspect & Area of Interest \\
\hline $\begin{array}{c}G T, t_{p} \\
G T, t_{p}, P A X\end{array}$ & $\begin{array}{c}\mathrm{kg} \\
\mathrm{kWh} / \mathrm{PAX} / \mathrm{h}\end{array}$ & $\begin{array}{l}\text { Green house gas } \\
\text { emissions } \\
\text { Energy efficiency }\end{array}$ & $\begin{array}{l}\text { Environmental impact } \\
\text { and resource use }\end{array}$ & Environmental \\
\hline $\begin{array}{c}\text { PAX } \\
\text { PAX, GT }\end{array}$ & $\begin{array}{l}\mathrm{NOK} \\
\mathrm{NOK}\end{array}$ & $\begin{array}{l}\text { Spending potential } \\
\text { Port fee }\end{array}$ & $\begin{array}{l}\text { Equitable distribution } \\
\text { of economic benefits }\end{array}$ & Economic \\
\hline $\begin{array}{l}G T, t_{p}, Y B \\
P A X, t_{p}\end{array}$ & $\begin{array}{c}\mathrm{kg} \\
\mathrm{PAX} / \mathrm{h}\end{array}$ & $\begin{array}{l}\text { NOx emissions } \\
\text { Guest frequency }\end{array}$ & $\begin{array}{l}\text { Minimizing negative } \\
\text { social/health impacts }\end{array}$ & Social \\
\hline
\end{tabular}

\subsection{Step 3-Testing the Indicators}

\subsubsection{Environmental Impact}

Under the critical constraints encompassing the time and other resources needed for accessing and modeling data to compute sustainability indicators, the scoring model proposed in the current study comes with limitations in this regard as only the hotel phase of cruise ship operations in port are covered by the sustainability scoring system. The combined variable port time and GT is found through regression modelling to be the best independent variables to predict emissions from cruise ship hoteling at port [16]. The proposed indicator for greenhouse gas (GHG) emissions per cruise call presented in the scoring model is hence based on a regression model for hotel power demand (E) for cruise ship hotel power provided by the authors [54]. E is further multiplied by $t_{p}$ and the emissions factor for greenhouse gas emissions given as $\mathrm{kg} \mathrm{CO}_{2}$ per $\mathrm{kWh}$ from the third IMO greenhouse gas study [55]. Greenhouse gas emissions were estimated for all cruise calls at Geiranger for the years 2015 to 2019. The interquartile range has remained steady in the period and the median has increased (Figure 3). E is also suitable for the energy efficiency indicator proposed in the scoring model, but rather than multiplying with an emissions factor it is divided by PAX and $t_{p}$. This gives an indicator presenting how much energy is allocated to each of the passengers in the cruise ship. The energy efficiency indicator (Figure 4) gives many more outliers than any of the other indicators, 
yet the median is on the lower band of the interquartile range. This is due to ships with a high passenger-to-space ratio, meaning that the ships are relatively large compared to the number of passengers. Looking at the details behind the statistical summaries, it is apparent that there is a trend of ships with the highest passenger count are the most energy efficient.

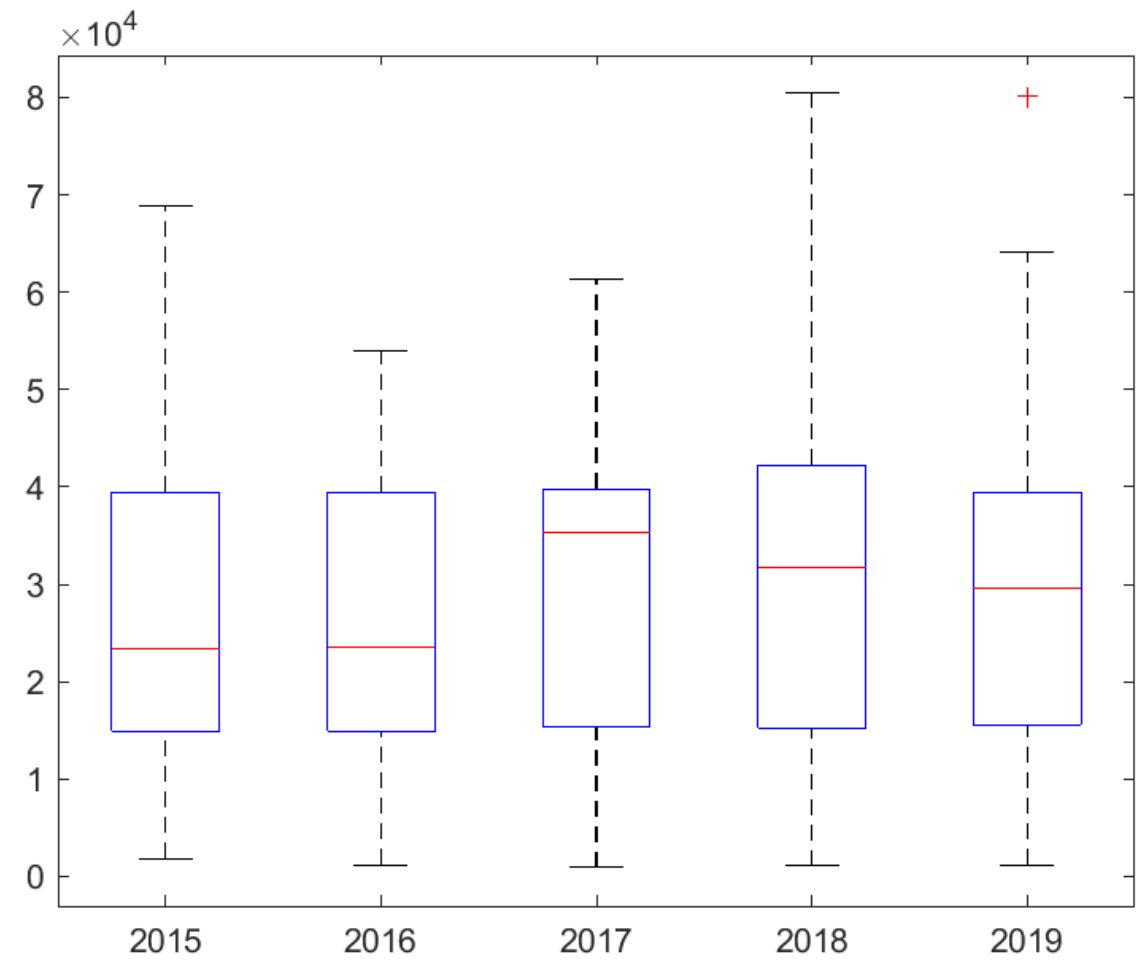

Figure 3. Estimated greenhouse gas emissions [kg] per cruise ship call in Geiranger from 2015-2019, $n=937$.



Figure 4. Estimated energy efficiency [kWh/PAX/h] per cruise ship call in Geiranger from 2015-2019, $n=937$. 


\subsubsection{Equitable Distribution of Economic Benefits}

When cruise calls are ordered by operators the port authority at least knows the passenger capacity of the given ship. Spending potential (SP) is given as the number of passengers multiplied by the average cruise passenger spending factor related to a cruise call for the given port, region or country. The spending factor (SF) gives how much money each cruise passenger on average spends when they go ashore at cruise destinations. The spending factor is normally gathered through surveying cruise passengers to a specific geographical area. The PAX data given for a cruise ship itinerary is commonly in the planning phase of a cruise call based on the passenger capacity of the vessel. It is not common that all passengers disembark the cruise ship at each port call. When calculating spending potential, PAX is multiplied by the landing factor (LF), giving how large percentage of total PAX is going ashore on average. The specific landing factor used when calculating the case data for Geiranger is provided by Stranda Port Authority as between $0.5-0.8$ for this specific port. The value for SF for the port of Geiranger is for the data presented in this article LF $=0.7$ and SF $=460 \mathrm{NOK}$ [56]. The study also tried to see if the longer the guests stay, the higher is the possibility to spend money on local shops, cafes, etc. [56]. This effect, however, is not quantified in the scoring model in other ways than that cruise calls which have $p_{t}<2$ are assumed not landing passengers due to time restrictions, hence giving a spending potential of zero. The port fee (PF) indicator gives how much the cruise ships must pay the local port authorities to use the quay. How the port fee is calculated could differ among ports. For the case of Geiranger, the rules for equating the port fee are extracted from the port authority web pages. Both spending potential and port fee are considered benefits in the scoring model and are hence considered variables that should be maximized.

\subsubsection{Minimizing Negative Social/Health Impacts}

Social indicators are considered as indicators impacting the well-being of both visitors and local inhabitants. Indicators dealing with emissions to air are considered core indicators, suggesting indicators stating the amount of emissions $\left(\mathrm{SO}_{\mathrm{x}}, \mathrm{NO}_{\mathrm{x}}, \mathrm{PM}\right)$ per cruise passenger and the number of days where air quality standards are exceeded for the given pollutants [29]. At the same time, one also could consider the air pollutants with local effects as environmental indicators. Exposure to $\mathrm{NO}_{\mathrm{x}}$ may cause impaired lung function, increased susceptibility to respiratory infections and development or worsening of asthma and bronchitis [57]. Although air quality measurements for Geiranger show few occurrences of emissions exceeding the threshold levels for air pollution in national and international regulations, the studies show that the emissions are frequently above the Norwegian Institute of Public Health's air quality criteria during the tourist season [58]. Although the tourist season does not span over the whole year it is still a significant period of the year with significant pollution levels. The purpose of air quality criteria is to prevent negative health effects due to air pollution. The emissions concentrations in the criteria are set so low that most people can be exposed to these levels without suffering harmful health effects. Based upon these arguments the authors of this paper propose that NOx emissions are considered as a social indicator as they affect the health and well-being of local inhabitants and visitors. The guest frequency indicator alludes to the notion of crowding or "people pollution" [4]. The guest frequency (GF) factor is calculated by PAX onshore/port hours. It gives an expression of how many people to be landed/berthed per time unit. Less time also means less time to disperse, meaning more traffic and more crowding.

\subsection{Step 4-Decision Support}

The fourth step in the methodology proposed in Figure 1 requires that using the indicators is dependent on the management and decision-making context. This includes performing planning and management operations such as assessing port call requests on both a long-term and day-to-day basis, as well as invoking abatement measures to reduce 
strains or bolster opportunities. Other identified needs were information to support longterm strategic planning as well as the means to communicate towards stakeholders such as actors in the local community as well as cruise corporations and government bodies.

\subsubsection{Port Management and Planning}

Spending potential and port fee was estimated for all cruise calls coming to Geiranger from 2015 to 2019. These indicators are directly linked to the benefits of having cruise ships visiting the port for local business and the port owner, respectively. The trade-off between benefits and externalities is a central challenge for the port authority. From Table 2 one could observe that both the estimated cumulative spending per cruise call and port fee has increased over the five years, but so have the greenhouse gas emissions as well. This information could be useful for port operators in order to see both the benefit and cost of having more or less cruise tourists going ashore at their destination. Also, it could be useful to see whether, if ships were only to dock and do not let tourists ashore, the port fee might still keep up at high levels, but that would weaken the potential for businesses to generate income. The guest frequency indicator provides a means for port operators to say how many tourists the area needs to absorb. The average number of cruise passengers ashore has remained stable over the five years. A high value on this indicator means that many tourists disembark, are distributed, and board the ship within a specific time window. Decision makers could use this information to observe over time if there are correlations between the indicator and what is observed outside considering the destination's ability to absorb the number of tourists ashore. In this way, anecdotal reports of "crowding" could be related to the guest frequency number and, with many observations, the port operators could potentially gain an idea of whether there are levels of guest frequency when there is an increased risk of experiencing oversaturation of people in the area. This information could further be used to forecast such events and plan measures to abate the issue in advance.

Table 2. Cumulative scoring system indicators for cruise calls to Geiranger 2015-2019.

\begin{tabular}{ccccccc}
\hline \multirow{2}{*}{ Year } & \multicolumn{2}{c}{ Environmental } & \multicolumn{2}{c}{ Economic } & \multicolumn{2}{c}{ Social } \\
\cline { 2 - 7 } & $\begin{array}{c}\text { GHG } \\
\text { Emissions } \\
{[\text { ktonnes] }}\end{array}$ & $\begin{array}{c}\text { Hotel } \\
\text { Energy Use } \\
{[\text { [GWh] }}\end{array}$ & $\begin{array}{c}\text { Spending } \\
\text { Potential } \\
\text { [MNOK] }\end{array}$ & $\begin{array}{c}\text { Port Fee } \\
\text { [MNOK] }\end{array}$ & $\begin{array}{c}\text { NOx } \\
\text { Emissions } \\
\text { [Tonnes] }\end{array}$ & $\begin{array}{c}\text { Number of } \\
\text { Tourists } \\
\text { 000 [PAX] }\end{array}$ \\
\hline 2019 & 5.47 & 7.74 & 132 & 20.9 & 71.3 & 288 \\
2018 & 5.06 & 7.16 & 114 & 18.1 & 64.3 & 250 \\
2017 & 4.97 & 7.02 & 117 & 18.3 & 71.4 & 255 \\
2016 & 4.52 & 6.39 & 106 & 16.7 & 70.1 & 230 \\
2015 & 4.34 & 6.14 & 106 & 16.4 & 69.7 & 229 \\
\hline
\end{tabular}

\subsubsection{Scenario Evaluation}

Considering strategic planning, quantifying greenhouse gas emissions could be used for setting targets and goals and to evaluate the impacts of future policies. Setting a target for cumulative and median greenhouse gas emissions over a season are examples of goals for which this indicator could be used (Tables 2 and 3). Furthermore, policies could be implemented, such as incentivizing cold-ironing or LNG ships and the indicator could be used to see whether these policies are having an effect. Utilizing this information could be valuable in a decision support sense as it provides port authorities information about which ships bring the most spending and port income per energy usage, which is directly proportional to emissions of both global and local pollutants. 
The NMA is uncertain whether the cruise industry will be ready for zero emissions in 2026 and, therefore, suggest postponing to 2030, while still keeping Tier III for 2025 [59]. The year 2025 was selected for the scenario, using the Tier III compliant cruise ships scheduled to come to Geiranger in 2020 (before the COVID-19 pandemic brought cruise tourism to a halt) as a proxy. After discussing with local port authorities, it was concluded that making any good prognosis for future cruise tourist visits would be very uncertain due to the unknown short to medium-term effects of the pandemic. The case of emulating 2025 through 2020 was therefore accepted as sufficient for the sake of illustrating the scoring system for scenario evaluation.

Table 3. Average scoring system indicators per cruise calls in Geiranger 2015-2019.

\begin{tabular}{|c|c|c|c|c|c|c|}
\hline & \multicolumn{2}{|c|}{ Environmental } & \multicolumn{2}{|c|}{ Economic } & \multicolumn{2}{|c|}{ Social } \\
\hline & $\begin{array}{c}\text { GHG } \\
\text { Emissions } \\
\text { [tonnes] }\end{array}$ & $\begin{array}{c}\text { Energy } \\
\text { Efficiency } \\
{[\mathbf{k W h} / \mathbf{P A X} / \mathbf{h}]}\end{array}$ & $\begin{array}{l}\text { Spending } \\
\text { Potential } \\
\text { [MNOK] }\end{array}$ & $\begin{array}{c}\text { Port Fee } \\
\text { [MNOK] }\end{array}$ & $\begin{array}{c}\mathrm{NO}_{\mathbf{x}} \\
\text { Emissions } \\
{[\mathrm{kg}]}\end{array}$ & $\begin{array}{c}\text { GF } \\
\text { [PAX } \\
\text { Onshore/Port } \\
\text { Hours] }\end{array}$ \\
\hline 2019 & 25.9 & 3.06 & 0.63 & 0.10 & 338 & 183 \\
\hline 2018 & 27.5 & 3.25 & 0.62 & 0.10 & 350 & 178 \\
\hline 2017 & 27.7 & 3.07 & 0.65 & 0.10 & 399 & 188 \\
\hline 2016 & 24.3 & 3.00 & 0.57 & 0.09 & 377 & 163 \\
\hline 2015 & 24.5 & 2.96 & 0.60 & 0.09 & 394 & 177 \\
\hline
\end{tabular}

Both $\mathrm{NO}_{\mathrm{x}}$ emissions and guest frequency are estimated on parameters explaining the size of the ship. Gross tonnage and number of passengers respectively. Due to this one should expect that since greenhouse gas emissions have increased together with the number of passengers the same should apply for $\mathrm{NO}_{\mathrm{x}}$ emissions as they are both estimated based on the energy demand. However, this is not the case for the historical data from 2015 to 2019 (Table 2). A possible explanation for this are the policies related to $\mathrm{NO}_{\mathrm{x}}$ Tier-standards, requiring ships with lower $\mathrm{NO}_{\mathrm{x}}$ emissions. One could based on this observation speculate that the $\mathrm{NO}_{x}$ Tier standard policies have been successful over the five-year period as average spending has increased while median $\mathrm{NO}_{\mathrm{x}}$ pollution has stayed still. Regarding the future scenario, results from Table 4 show that there will be a significant reduction in the total number of tourists and spending potential, both with a decrease of 55\% from 2019. Cumulative greenhouse gas emissions will decrease even more by $63 \%$ and NOx by $92 \%$. These estimates would suggest that the reduction in environmental impact would be greater than the loss in income. When looking at the results from Table 5 one could see that although the cumulative greenhouse gas emissions are decreasing, the emissions per cruise call have increased. The average energy efficiency has also worsened. The explanation of why this might be the case could be due to the more uneven configuration coming to Geiranger under the assumptions made for the case study, as it is either very large or relatively small ships, with the ships in the mid-size class not being as represented as they were historically. One could also see this in the average guest frequency, meaning that although the cumulative number of tourists has drastically declined, the flux of tourists when ships call to port will increase. This could be valuable information when planning how to organize for receiving tourists in the future or considering new regulations. In this specific case the average capacity to absorb tourists through landing boats and distribution with buses etc. needs to remain the same even though the total number and hence possibility for income decreases. Effects like this will be very interesting to study in forthcoming work related to the 2026 zero-emissions regulations being addressed by the authors of the current study. 
Table 4. Cumulative scoring system indicators for cruise calls to Geiranger 2019 and 2025.

\begin{tabular}{ccccccc}
\hline & \multicolumn{2}{c}{ Environmental } & \multicolumn{2}{c}{ Economic } & \multicolumn{2}{c}{ Social } \\
\hline Year & $\begin{array}{c}\text { GHG } \\
\text { Emissions } \\
{[\text { ktonnes] }}\end{array}$ & $\begin{array}{c}\text { Hotel } \\
\text { Energy Use } \\
{[\text { [GWh] }}\end{array}$ & $\begin{array}{c}\text { Spending } \\
\text { Potential } \\
{[\text { [MNOK] }}\end{array}$ & $\begin{array}{c}\text { Port Fee } \\
{[\text { MNOK] }}\end{array}$ & $\begin{array}{c}\text { NO }_{\mathbf{x}} \\
\text { Emissions } \\
{[\text { Tonnes] }}\end{array}$ & $\begin{array}{c}\text { Number of } \\
\text { Tourists } \\
\text { ‘000 [PAX] }\end{array}$ \\
\hline 2025 & 2.01 & 3.31 & 59.4 & 9.18 & 5.70 & 129 \\
2019 & 5.47 & 7.74 & 132 & 20.9 & 71.3 & 288 \\
\hline
\end{tabular}

Table 5. Average scoring system indicators per cruise call to Geiranger 2015 and 2025.

\begin{tabular}{ccccccc}
\hline \multicolumn{2}{c}{ Environmental } & \multicolumn{2}{c}{ Economic } & \multicolumn{2}{c}{ Social } \\
\hline $\begin{array}{c}\text { GHG } \\
\text { Emissions } \\
{[\text { Tonnes] }}\end{array}$ & $\begin{array}{c}\text { Energy } \\
\text { Efficiency } \\
{[\mathbf{k W h} / \mathbf{P A X / h}]}\end{array}$ & $\begin{array}{c}\text { Spending } \\
\text { Potential } \\
{[\text { [NOK] }}\end{array}$ & $\begin{array}{c}\text { Port Fee } \\
{[\text { NOK] }}\end{array}$ & $\begin{array}{c}\text { NO }_{\mathbf{x}} \\
\text { Emissions } \\
{[\mathbf{k g}]}\end{array}$ & $\begin{array}{c}\text { GF } \\
\text { [PAX } \\
\text { Onshore/Port } \\
\text { Hours] }\end{array}$ \\
\hline 2025 & 30.5 & 3.52 & 0.90 & 0.14 & 86.4 & 230 \\
2019 & 25.9 & 3.06 & 0.63 & 0.10 & 338 & 183 \\
\hline
\end{tabular}

\subsubsection{Communication with Stakeholders}

In terms of stakeholder communication, the output from indicators could be valuable to use for informing with quantifiable information on sustainability [29]. Daily or percruise call values of the indicators could prove useful information to actors dependent or affected by cruise tourism. The spending potential indicator could prove useful for local business to forecast their revenue and enable better staffing for the given cruise call days. Together with information on GF for a given day, personnel and service level could be tailored based upon this information. In Geiranger, cruise calls are often booked a year or two in advance and therefore the indicators from the proposed scoring system could be communicated to local businesses in advance providing forecast information on the market and a better foundation to choose strategies and investments. Communicating openly on these benefits could also provide more approval of cruise tourism from stakeholder groups with a negative view of the industry. Conversely, the GF indicator could be valuable for people wanting to visit Geiranger on more calm days, avoiding the busiest days and allowing for a more even distribution of visitors. Communicating indicators of local air pollution, like the $\mathrm{NO}_{\mathrm{x}}$ indicator, could provide useful information for people sensitive to aerosols. Knowing that there will be potentially large emissions, one could choose to stay out of Geiranger if there are e.g., are weather conditions that tend to worsen air pollution. Using historical information on ship activity and pollutant levels can provide a way of forecasting air pollution levels [60]. The results from the indicator could also be communicated to governing bodies and other stakeholders like greenhouse gas accounting initiatives.

\subsection{Step 5-Evaluation}

The resulting scoring model provides indicators that may evaluate various sustainability aspects related to cruise calls in both short and long-term perspectives using openly available data. The proposed sustainability scoring model for cruise ships at port has several technical and practical properties that are valuable for cruise port operators and owners. Firstly, the approach is practical, with a low barrier for implementation. This assertion is based upon the fact that the basic input variables to the scoring model are basic cruise call itinerary data and supplementary data that are openly available. Secondly, the scoring model provides estimates on six indicators representing the social, environmental and economic aspects of sustainability and also could be mapped in accordance with the relevant UN Sustainable Development Goals (SDGs) [61]. The indicators are useful when port operators and/or owners seek decision support with aim of enabling sustainability as 
a control parameter as well as utilizing them for communication with stakeholders. Thirdly, the scoring model is open to assigning weights among the criteria expressed through the indicators. Regarding matters which could be improved, the model could benefit from also including indicators addressing the effect of cruise tourism on onshore traffic strains as tourists are further distributed in the area by bus [62]. The relative importance and/or severity among the criteria expressed in the scoring model could be perceived differently between ports depending on their unique characteristics. Optimizing only one of the criteria does not guarantee the most advantageous solution.

\section{Conclusions and Further Work}

Balancing the impact of cruise traffic for port operators is challenging and often requires access to extensive tools and methods, while a practical/screening approach is missing. The information gained through the cruise call sustainability scoring model as demonstrated in this paper will, therefore, be a valuable contribution to support decisions in further management. The model provides data on six sustainability indicators based on calculations from readily available cruise call data. This information is then used to determine which measures to invoke for countering environmental and social strains to the port and its vicinity, at the same time balancing it with the economic gains from the activity. The case as demonstrated for the port of Geiranger, Norway, indicates that the cruise call sustainability scoring and decision support model is valuable in practice and beneficial for the cruise traffic port operators in the implementation of the SDGs in operational management procedures.

Scholars investigating sustainability in management and decision support may find the current study relevant as it includes a systems approach to establish and implement the SDGs for practical use. However, we acknowledge there are other models which are more comprehensive like the sustainability indicator sets by e.g., Stefanidaki and Lekakou [29] or $\mathrm{Wu}, \mathrm{Chen}$ and $\mathrm{Min}$ [30], while the model proposed in this study uses an alternative approach, thus being more focused on practicality and low threshold for implementation than the currently available models. To increase the comprehensiveness of the model, more indicators can be included such as other emission factors, shore power availability, discharge to water, visual pollution and other means of local inhabitants and visitors' perceptions of a cruise call. The cumulative strain from multiple and simultaneous cruise calls could also be considered an improvement to the model.

The model could further be extended in its application by adding a multi-criteria decision making (MCDM) component. Instead of being static in the decision support stage, exploring how different stakeholder group perceptions give preference to different ship types through weighting schemes may further increase the possibility of making a balanced decision with credibility among a broad range of stakeholders [63]. Knowledge of how difference in opinions may lead to possible trade-offs may also aid the future strategic decision on the development of tourism destinations and cruise port operations. This will be the topic in a forthcoming study where the sustainability scoring model will be implemented with MCDM methodology for the appraisal of future scenarios of port infrastructure development in the Geirangerfjord area.

Author Contributions: Conceptualization, B.H.J., V.Æ. and D.M.A.; methodology, B.H.J., D.M.A. and M.S.; validation, B.H.J. and D.M.A.; formal analysis, B.H.J.; data curation, B.H.J.; writing-original draft preparation, B.H.J. and D.M.A.; writing-review and editing, B.H.J., D.M.A., M.S. and V.Æ.; supervision, V.Æ.; project administration, D.M.A.; funding acquisition, D.M.A. All authors have read and agreed to the published version of the manuscript.

Funding: This research was funded by the Norwegian Research Council, grant number 267887.

Acknowledgments: The authors are grateful for the participation and knowledge sharing from local actors in the Geiranger area, including Stranda Port Authority in particular. 
Conflicts of Interest: The authors declare no conflict of interest. The funders had no role in the design of the study; in the collection, analyses, or interpretation of data; in the writing of the manuscript; or in the decision to publish the results.

\section{References}

1. Cruise Lines International Association. State of the Cruise Industry Outlook 2020; CLIA: London, UK, 2020.

2. Cruise Lines International Association. State of the Cruise Industry Outlook 2021; CLIA: London, UK, 2021.

3. Copeland, C. Cruise ship pollution: Background, laws and regulations, and key issues. In Maritime Law: Issues, Challenges and Implications; Harris, J.W., Ed.; Nova Science Publishers, Inc.: New York, NY, USA, 2011.

4. Klein, R.A. Responsible Cruise Tourism: Issues of Cruise Tourism and Sustainability. J. Hosp. Tour. Manag. 2011, 18, 107-116. [CrossRef]

5. Carić, H. Cruising Tourism Environmental Impacts: Case Study of Dubrovnik, Croatia. J. Coast. Res. 2011, 61, 104-113. [CrossRef]

6. Maragkogianni, A.; Papaefthimiou, S. Evaluating the social cost of cruise ships air emissions in major ports of Greece. Transp. Res. Part. D Transp. Environ. 2015, 36, 10-17. [CrossRef]

7. Papaefthimiou, S.; Maragkogianni, A.; Andriosopoulos, K. Evaluation of cruise ships emissions in the Mediterranean basin: The case of Greek ports. Int. J. Sustain. Transp. 2016, 10, 985-994. [CrossRef]

8. Scarfe, B.L. Victoria as a Port-of-Call: The Costs and Benefits of Cruise Ship Visits; James Bay Neighbourhood Association: Victoria, BC, Canada, 2011.

9. $\quad$ Elkington, J. Cannibals with Forks: The Triple Bottom Line of 21st Century Business; Capstone Publishing Ltd.: Oxford, UK, 1997.

10. Ritter, W.; Schafer, C. Cruise-Tourism: A Chance of Sustainability. Tour. Recreat. Res. 1998, 23, 65-71. [CrossRef]

11. Carić, H.; Mackelworth, P. Cruise tourism environmental impacts-The perspective from the Adriatic Sea. Ocean. Coast. Manag. 2014, 102, 350-363. [CrossRef]

12. Miola, A.; Ciuffo, B. Estimating air emissions from ships: Meta-analysis of modelling approaches and available data sources. Atmos. Environ. 2011, 45, 2242-2251. [CrossRef]

13. Poplawski, K.; Setton, E.; McEwen, B.; Hrebenyk, D.; Graham, M.; Keller, P. Impact of cruise ship emissions in Victoria, BC, Canada. Atmos. Environ. 2011, 45, 824-833. [CrossRef]

14. Mölders, N.; Gende, S.; Pirhalla, M. Assessment of cruise-ship activity influences on emissions, air quality, and visibility in Glacier Bay National Park. Atmos. Pollut. Res. 2013, 4, 435-445. [CrossRef]

15. Carić, H. Challenges and prospects of valuation-cruise ship pollution case. J. Clean. Prod. 2016, 111, 487-498. [CrossRef]

16. Rodríguez, G.D.M.; Martin-Alcalde, E.; Murcia-González, J.; Saurí, S. Evaluating air emission inventories and indicators from cruise vessels at ports. WMU J. Marit. Aff. 2017, 16, 405-420. [CrossRef]

17. Simonsen, M.; Walnum, H.J.; Gössling, S. Model for Estimation of Fuel Consumption of Cruise Ships. Energies 2018, 11, 1059. [CrossRef]

18. Murena, F.; Mocerino, L.; Quaranta, F.; Toscano, D. Impact on air quality of cruise ship emissions in Naples, Italy. Atmos. Environ. 2018, 187, 70-83. [CrossRef]

19. Ruiz-Guerra, I.; Molina-Moreno, V.; Cortés-García, F.J.; Núñez-Cacho, P. Prediction of the impact on air quality of the cities receiving cruise tourism: The case of the Port of Barcelona. Heliyon 2019, 5, e01280. [CrossRef] [PubMed]

20. Dragović, B.; Tzannatos, E.; Tselentis, V.; Meštrović, R.; Škurić, M. Ship emissions and their externalities in cruise ports. Transp. Res. Part. D Transp. Environ. 2018, 61, 289-300. [CrossRef]

21. Paoli, C.; Vassallo, P.; Dapueto, G.; Fanciulli, G.; Massa, F.; Venturini, S.; Povero, P. The economic revenues and the emergy costs of cruise tourism. J. Clean. Prod. 2017, 166, 1462-1478. [CrossRef]

22. McArthur, D.P.; Osland, L. Ships in a city harbour: An economic valuation of atmospheric emissions. Transp. Res. Part. D Transp. Environ. 2013, 21, 47-52. [CrossRef]

23. Johnson, D. Environmentally sustainable cruise tourism: A reality check. Mar. Policy 2002, 26, 261-270. [CrossRef]

24. Brida, J.G.; Zapata-Aguirre, S. Cruise Tourism: Economic, Socio-Cultural and Environmental Impacts. Int. J. Leis. Tour. Mark. 2009, 1, 22. [CrossRef]

25. Hritz, N.; Cecil, A.K. Investigating the Sustainability of Cruise Tourism: A Case Study of Key West. J. Sustain. Tour. 2008, 16, 168-181. [CrossRef]

26. Pomeranz, E.F.; Needham, M.D.; Kruger, L.E. Stakeholder Perceptions of Indicators of Tourism Use and Codes of Conduct in a Coastal Protected Area in Alaska. Tour. Mar. Environ. 2013, 9, 95-115. [CrossRef]

27. James, L.; Olsen, L.S.; Karlsdóttir, A. Sustainability and cruise tourism in the arctic: Stakeholder perspectives from Ísafjörður, Iceland and Qaqortoq, Greenland. J. Sustain. Tour. 2020, 28, 1425-1441. [CrossRef]

28. McCaughey, R.; Mao, I.; Dowling, R. Residents' perceptions towards cruise tourism development: The case of Esperance, Western Australia. Tour. Recreat. Res. 2017, 43, 403-408. [CrossRef]

29. Stefanidaki, E.; Lekakou, M. Cruise carrying capacity: A conceptual approach. Res. Transp. Bus. Manag. 2014, 13, 43-52. [CrossRef]

30. Wu, X.; Chen, H.; Min, J. Sustainability assessment of cruise-industry development: A case study of Xiamen, China. Marit. Policy Manag. 2020, 1-12. [CrossRef] 
31. Gunn, C.A. Tourism Planning, 4th ed.; Routlege: New York, NY, USA, 2002.

32. Arnold, R.D.; Wade, J.P. A Definition of Systems Thinking: A Systems Approach. Procedia Comput. Sci. 2015, 44, 669-678. [CrossRef]

33. Schianetz, K.; Kavanagh, L.; Lockington, D. The Learning Tourism Destination: The potential of a learning organisation approach for improving the sustainability of tourism destinations. Tour. Manag. 2007, 28, 1485-1496. [CrossRef]

34. Walker, P.A.; Greiner, R.; McDonald, D.; Lyne, V. The Tourism Futures Simulator: A systems thinking approach. Environ. Model. Softw. 1998, 14, 59-67. [CrossRef]

35. Dawson, J.; Maher, P.T.; Slocombe, S.D. Climate Change, Marine Tourism, and Sustainability in the Canadian Arctic: Contributions from Systems and Complexity Approaches. Tour. Mar. Environ. 2007, 4, 69-83. [CrossRef]

36. Stanitsas, M.; Kirytopoulos, K.; Leopoulos, V. Integrating sustainability indicators into project management: The case of construction industry. J. Clean. Prod. 2021, 279, 123774. [CrossRef]

37. Steiniger, S.; Wagemann, E.; De La Barrera, F.; Molinos-Senante, M.; Villegas, R.; De La Fuente, H.; Vives, A.; Arce, G.; Herrera, J.C.; Carrasco, J.-A.; et al. Localising urban sustainability indicators: The CEDEUS indicator set, and lessons from an expert-driven process. Cities 2020, 101, 102683. [CrossRef]

38. Coccossis, H.; Koutsopoulou, A. Measuring and monitoring sustainability of coastal tourism destinations in the Mediterranean. Tourism 2020, 68, 482-498. [CrossRef]

39. Schianetz, K.; Kavanagh, L. Sustainability Indicators for Tourism Destinations: A Complex Adaptive Systems Approach Using Systemic Indicator Systems. J. Sustain. Tour. 2008, 16, 601-628. [CrossRef]

40. Roxas, F.M.Y.; Rivera, J.P.R.; Gutierrez, E.L.M. Framework for creating sustainable tourism using systems thinking. Curr. Issues Tour. 2020, 23, 280-296. [CrossRef]

41. Kerswill, M.; Mair, H. Big Ships, Small Towns: Understanding Cruise Port Development in Falmouth, Jamaica. Tour. Mar. Environ. 2015, 10, 189-199. [CrossRef]

42. Waas, T.; Hugé, J.; Block, T.; Wright, T.; Benitez-Capistros, F.; Verbruggen, A. Sustainability Assessment and Indicators: Tools in a Decision-Making Strategy for Sustainable Development. Sustainability 2014, 6, 5512-5534. [CrossRef]

43. Pesce, M.; Terzi, S.; Al-Jawasreh, R.I.M.; Bommarito, C.; Calgaro, L.; Fogarin, S.; Russo, E.; Marcomini, A.; Linkov, I. Selecting sustainable alternatives for cruise ships in Venice using multi-criteria decision analysis. Sci. Total Environ. 2018, 642, 668-678. [CrossRef]

44. Fet, A.M. Systems Engineering Methods and Environmental Lifecycle Performance within Ship Industry. Ph.D. Thesis, Norwegian University of Science and Technology, Trondheim, Norway, 1997.

45. Haskins, C. Systems Engineering Analyzed, Synthesized, and Applied to Sustainable Industrial Park Development. Ph.D. Thesis, Norwegian University of Science and Technology, Trondheim, Norway, 2008.

46. Cruise Norway, 2019 Cruise Calls and Pax to Norway. 2020. Available online: https://www.cruise-norway.no/Public-info/ Statistics / (accessed on 13 October 2020).

47. Shlopak, M.; Bråthen, S.; Svendsen, H.J.; Oterhals, O. Grønn Fjord. Bind II. Beregning av Klimagassutslipp i Geiranger; Møreforsking Molde AS: Molde, Norway, 2014.

48. Norwegian Maritime Authority. Utslipp til Luft og sjø fra Skipsfart i fjordområder med stor cruisetrafikk, Report ver; Norwegian Maritime Authority: Haugesund, Norway, 2017.

49. Yttredal, E.R.; Homlong, N. Perception of Sustainable Development in a Local World Heritage Perspective. Sustainability 2020, 12, 8825. [CrossRef]

50. Yttredal, E.R.; Homlong, N. Besøkendes Opplevelse av Geirangerområdet; Volda University College: Volda, Norway, 2019.

51. Norwegian Parliamient. Klimastrategi for 2030-Norsk Omstilling i Europeisk Samarbeid; E.-A.E. Committee: Oslo, Norway, 2018.

52. Norwegtian Minsitry of Climate and Environment. Forskrift om Miljømessig Sikkerhet for Skip og Flyttbare Innretninger; Norwegtian Minsitry of Climate and Environment: Oslo, Norway, 2020.

53. IHS-Markit. Sea-Web Ships. 2018. Available online: https:/ / maritime.ihs.com/ (accessed on 20 November 2020).

54. Johansen, B.A.H.; Aspen, D.M.; Sparrevik, M.; Æsøy, V. Air Emission Screening Approach for Sustainable Cruise Port Management. Manuscript submitted for publication. 2020.

55. Smith, T.; Smith Jalkanen, J.; Anderson, B.; Corbett, J.; Faber, J.; Hanayama, S.; O’Keeffe, E.; Parker, S.; Johansson, L.; Aldous LRaucci, C.; et al. Third IMO GHG Study 2014: Executive Summary and Final Report; IMO: London, UK, 2014.

56. Yttredal, E.R.; Homlong, N. Forbruk Blant Besøkende til Geirangerområdet; Volda University College: Volda, Norway, 2019.

57. World Health Organization. Ambient (Outdoor) Air Quality and Health Fact. Sheet, Updated September 2016; World Health Organization: Geneva, Switzerland, 2016.

58. Löffler, J. Long-Term Air Quality Monitoring Program. UNESCO World Natural Heritage "Geiranger Fjord”, Norway Annual Scientific Report 2020; Universität Bonn: Bonn, Germany, 2020.

59. Cruise Industry News. Norway Extends Zero-Discharge for Heritage Fjords to 2030. Available online: https://www. cruiseindustrynews.com/cruise-news/22871-norway-extends-zero-discharge-for-heritage-fjords-to-2030.html (accessed on 4 May 2020).

60. Aspen, D.M.; Löffler, J.; Hasle, E.; Ellefsen, A.L.; Kader, A.M.H.A.; Cheng, X.; Johansen, B.A.H. Prediction Modeling of Air Quality in Geiranger; Norwegian University of Science and Technology: Ålesund, Norway, 2019. 
61. United Nations. Transforming our World: The 2030 Agenda for Sustainable Development; United Nations: New York, NY, USA, 2015.

62. Díez-Gutiérrez, M.; Babri, S. Explanatory variables underlying the route choice decisions of tourists: The case of Geiranger Fjord in Norway. Transp. Res. Part. A Policy Pract. 2020, 141, 398-409. [CrossRef]

63. Belton, V.; Stewart, T. Multiple Criteria Decision Analysis: An. Integrated Approach; Springer Science Business Media: Berlin, Germany, 2002. 